Article

\title{
Composted Chicken Manure for Anaerobic Soil Disinfestation Increased the Strawberry Yield and Shifted the Soil Microbial Communities
}

\author{
Zhaoxin Song $\left.{ }^{1,2,3}{ }^{(}\right)$, Sebastien Massart ${ }^{3}{ }^{(0}$, Dongdong Yan ${ }^{1,2}$, Hongyan Cheng ${ }^{1}$, Mathilde Eck ${ }^{3}$, \\ Chadi Berhal ${ }^{3}$, Canbin Ouyang ${ }^{1,2}$, Yuan Li ${ }^{1,2}$, Qiuxia Wang ${ }^{1,2}$ and Aocheng Cao ${ }^{1,2, *}$ \\ 1 Institute of Plant Protection, Chinese Academy of Agricultural Sciences, Beijing 100193, China; \\ zhaoxin.song@student.uliege.be (Z.S.); yandongdong@caas.cn (D.Y.); chenghongyan@caas.cn (H.C.); \\ oycblwy@sina.com (C.O.); liyuancaas@126.com (Y.L.); wangqiuxia@caas.cn (Q.W.) \\ 2 Beijing Innovation Consortium of Agriculture Research System, Beijing 100029, China \\ 3 Integrated and Urban Phytopathology Laboratory, University of Liege, Gembloux Agro-Bio Tech, Passage \\ des Deportes 2, 5030 Gembloux, Belgium; sebastien.massart@ulg.ac.be (S.M.); mathilde.eck@uliege.be (M.E.); \\ chadi.berhal@doct.uliege.be (C.B.) \\ * Correspondence: caoac@vip.sina.com
}

Received: 29 May 2020; Accepted: 23 July 2020; Published: 5 August 2020

\begin{abstract}
Anaerobic soil disinfestation (ASD), as a bio-fumigation technology, has been developed to control soil-borne pests. There is increasing evidence showing that carbon sources and cover tarps play an important role in the ASD suppression of soil-borne pests, but little is known about the effect of composted chicken manure (CCM) and totally impermeable films (TIF) against soil-borne pests in the strawberry production system. In experiments, the colonies of Fusarium spp. and Phytophthora spp., which are recognized to cause strawberry soil-borne diseases, decreased significantly after ASD. The soil promoted a significant increase in ammonium nitrogen, nitrate-nitrogen and organic matter, but a decrease in oxidation-reduction potential after ASD. Besides, the strawberry plant height, stem thickness and yield were significantly higher than in the non-amended soil. Compared to the untreated control, ASD, both at 6 and 12 ton/ha of CCM, significantly ( $p=0.05)$ increased strawberry marketable yield and income. The economic benefit could be due to the suppression of soil-borne diseases and the improvement of soil nutrition. The soil bacterial and fungal diversity and richness increased after soil fumigation. The increased presence of biological control agents led to the suppression of soil-borne pathogens. In summary, ASD with CCM amendments could be applied in pre-plant fumigation to control strawberry soil-borne pests, strengthen soil fertility, improve crop yield and increase growers' income.
\end{abstract}

Keywords: anaerobic soil disinfestation; soil physical and chemical indicators; strawberry yield; soil microbiota

\section{Introduction}

Soil-borne diseases are caused by fungi, bacteria, weeds and underground pests, and lead to severe crop losses [1,2]. Nonetheless, pre-plant soil fumigation technology is the main method for tackling strawberry soil-borne pests worldwide [3]. However, the chemical fumigants cause environmental problems and personal safety risks [4,5]. For example, chloropicrin (Cip) and 1,3-Dichloropropene $(1,3-D)$ are the major fumigants for strawberry plants, and are facing increased regulatory pressure around the world. [6,7]. Strawberry (Fragaria $\times$ ananassa) is a major high-economic crop, and plays an important role in increasing farmers' incomes [8]. Considering the long-term sustainability of 
strawberry production, the use biological or non-chemical disinfestation technology as an alternative to the chemical control of strawberry soil-borne pests should be evaluated [2].

The main non-chemical soil-borne management technologies include crop rotation, solar disinfestation, flooding, grafting on resistant rootstocks, steam disinfestation and anaerobic soil disinfestation (ASD) $[9,10]$. ASD combined with soil solarization can effectively control soil-borne diseases in bell peppers (Capsicum annum L.) and eggplants (Solanum melongena L.) [11]. ASD mainly affects by different kinds of carbon sources, including plant residue, animal manure and crop straws, and is coupled with assisted irrigation while the soil is mulched [12]. Different carbon sources used for ASD achieved different suppressions of pathogenic microorganisms [13]. At the same time, the effectiveness of ASD depends on various physical-chemical parameters of the soil; in particular, temperature plays a role in the effectiveness [14-16].

Composted organic amendments of ASD treatments have shown good suppressive activity on soil pathogens in the strawberry production regions [17]. Butler et al. [11] showed that a partially composted poultry litter amendment of ASD increased the bell pepper and the eggplant yields in the two harvest seasons, compared to the untreated control. Composted manure can improve soil fertility and plant growth, and contribute to the suppression of soil-borne pests [18,19]. The amount of livestock and poultry manure reached about 3.9 billion tons in 2007. More than 17 million tons of organic fertilizer is produced by composting animal manure, which is also considered as a cost-effective way to handle these waste each year in China $[20,21]$. The utilization of compost for ASD in strawberry production will become very important in the near future.

The goal of this research was to evaluate the suppressive activity of ASD, using compost as a carbon source, to control strawberry soil-borne pests in production systems. Composted chicken manure (CCM) was selected as a carbon source, and different amounts of CCM were tested in combination with a cover of totally impermeable film (TIF). ASD performance indicators, including fungi suppression, as well as impacts on plant growth, yield, economic income and soil quality, were selected to assess its effectiveness. At the same time, high-throughput sequencing (HTS) was used to monitor the shift of soil microbiota.

\section{Materials and Methods}

\subsection{Field Trials}

Field trials were carried out in Trial I (Jingjiao, $40^{\circ} 12^{\prime} 24.14^{\prime \prime} \mathrm{N}, 116^{\circ} 25^{\prime} 43.21^{\prime \prime} \mathrm{E}$ ) and Trial II (Daxing, $39^{\circ} 41^{\prime} 27.21^{\prime \prime} \mathrm{N}, 116^{\circ} 36^{\prime} 30.30^{\prime \prime}$ E) during the 2017-2018 season, Beijing, respectively. The greenhouses used for the field trials had continuously grown strawberry plants for many years, and faced high soil-borne disease pressures caused by Fusarium spp. and Phytophthora spp. (Table 1). All the greenhouses had never fumigated with chemical fumigation before the experiments. The soil was sandy loam (Trial I: $60 \%$ sand, $37 \%$ silt and $3 \%$ clay; $\mathrm{OM}=23.6 \mathrm{~g} \mathrm{~kg}^{-1} ; \mathrm{pH} 7.9$. Trial II: $57 \%$ sand, $37 \%$ silt and $6 \%$ clay; $\mathrm{OM}=13.0 \mathrm{~g} \mathrm{~kg}^{-1} ; \mathrm{pH} 7.5$, respectively.). The CCM $(23 \% \mathrm{C}, 3.8 \% \mathrm{P}$ and $3.4 \% \mathrm{~K} ; \mathrm{pH} 8.4)$ was from the Hebei Fengshou Green Organic Fertilizer Co., Ltd., and the 0.05-mm thickness TIF was provided by Shouguang Longxing Plastic Film Technology Co., Ltd., Shandong Province, China.

Table 1. Number of pathogens before disinfestation in soil at two trial sites.

\begin{tabular}{ccc}
\hline Trials & Fusarium spp. $\left(\mathbf{c f u ~ g}^{\mathbf{- 1}}\right)$ & Phytophthora spp. $\left(\mathbf{c f u} \mathbf{g}^{\mathbf{- 1}}\right.$ ) * \\
\hline Trial I (Jingjiao) & 4955 & 6539 \\
Trial II (Daxing) & 5455 & 6789 \\
\hline
\end{tabular}

* Value means the average of 4 parallel determinations before the soil disinfestation.

Three commercial greenhouses (two greenhouses in Trial I and one greenhouse in Trial II) were used for the field experiments. Before the tests started, the soil was ploughed twice with a 25-horsepower greenhouse rotary cultivator. According to the experimental design, the greenhouses 
were divided into 12 plots at each trial site. Each treatment was set up with 4 replicates in each trial site, and all plots were arranged in a completely randomized design. The areas of each plot of Trial I and Trial II were 22 and $28 \mathrm{~m}^{2}$, respectively. The treatments included: (1) 6 tons/ha composted chicken manure (CCM 6); (2) 12 tons/ha composted chicken manure (CCM 12); and (3) blank control (CK), no amendment. A TIF mulch was used to cover the soil in each plot. CCM 6 and CCM 12 were spread evenly on the soil surface. A rotary tiller was used to plough the plot again and the drip irrigation pipes were placed uniformly at 70-cm distances. According to our trial design, TIF was buried around each plot to prevent air exchange and water leakage. Finally, a drip irrigation system was used, and 50 tons/ha of water was applied. Each treatment was set up with 4 replicates in each trial site, and all plots were arranged in a completely randomized design. After covering the plot with TIF for 21 days, the film was opened and removed from each plot to allow air exchange for 7 days. The experiments were carried out on 27 June 2017 and 12 July 2017 for Trial I and Trial II, respectively. The strawberries (cultivar "Red Face") were transplanted on 28 August 2017 and 30 September 2017, in Trial I and Trial II, respectively.

\subsection{Soil Sampling}

The five soil samples method was used to take soil samples from the soil $(0-20 \mathrm{~cm}$ depth) in each plot at the sampling time. Soil samples were collected at 0 days (pre-fumigation), 30 days (post-fumigation, 26 July 2017 for Trial I and 10 August 2017 for Trial II) and 120 days (post-fumigation, 23 October 2017 for Trial I and 8 November 2017 for Trial II) from the 2 trial sites. After that, each soil sample was sieved through a 2-mm sieve, and sent in an icebox to the laboratory for analysis. Soil samples, collected in triplicates after 30 day-treatment, were analyzed in order to study soil-borne fungi and physical-chemical index. (a) $200 \mathrm{~g}$ of fresh soil was stored at $4{ }^{\circ} \mathrm{C}$ to isolate fungi pathogens. (b) $150 \mathrm{~g}$ of dry soil was passed through a 40-mm sieve, and stored at room temperature for soil physical and chemical analysis, and (c) $40 \mathrm{~g}$ fresh soil samples were collected in Trial II and stored at $-80^{\circ} \mathrm{C}$ for DNA extraction.

\subsection{Fungal Soil-Borne Pathogen Analysis}

The continuous cultivation of strawberries on the same land over many years has increased the risk of soil-borne diseases caused by Fusarium and Phytophthora [22,23]. The colonies of Fusarium spp. and Phytophthora spp. were isolated from $15 \mathrm{~g}$ fresh soil samples. Fusarium spp. and Phytophthora spp. were quantified using the methods described by Komada [24] and Masago [25], respectively.

The ingredients of selective media for the cultivation of Fusarium spp. and Phytophthora spp. were reported in (Table 2). Fungi colonies were cultured at $28^{\circ} \mathrm{C}$ for 3 days, and the quantity (colony-forming units (CFU) per $\mathrm{g}^{-1}$ soil) of fungi oomycetes was counted for data analysis.

Table 2. Culture medium composition (making $2 \mathrm{~L}$ of culture medium).

\begin{tabular}{|c|c|c|c|}
\hline Media * Category & Ingredients & Composition & References \\
\hline \multirow[b]{2}{*}{ Fusarium spp. } & A & $\begin{array}{c}\mathrm{K}_{2} \mathrm{HPO}_{4}(2 \mathrm{~g}), \mathrm{KCl}(1 \mathrm{~g}), \mathrm{MgSO}_{4}(1 \mathrm{~g}), \mathrm{L}-\text { Asparagine } \\
(4 \mathrm{~g}), \text { D Galactose }(40 \mathrm{~g}), \text { Agar (30 g). }\end{array}$ & \multirow[b]{2}{*}{ Komada [24] } \\
\hline & B & $\begin{array}{c}\text { Fe-Na EDTA }(0.02 \mathrm{~g}), \mathrm{Na}_{2} \mathrm{~B}_{4} \mathrm{O}_{7} \cdot 10 \mathrm{H}_{2} \mathrm{O}(2 \mathrm{~g}), \text { Oxgall } \\
(1 \mathrm{~g}) \text {, streptomycin sulfate }(1 \mathrm{~g}), \\
\text { Pentachloronitrobenzene (PCNB) }(1.5 \mathrm{~g})\end{array}$ & \\
\hline \multirow[b]{2}{*}{ Phytophthora spp. } & A & Agar $(34 \mathrm{~g})$, glucose $(40 \mathrm{~g})$. & \multirow[b]{2}{*}{ Masago [25] } \\
\hline & B & $\begin{array}{l}\text { Pentachloronitrobenzene (PCNB) }(0.15 \mathrm{~g}) \text {, Ampicillin } \\
(0.03 \mathrm{~g}) \text {, Rifampicina }(0.02 \mathrm{~g}) .\end{array}$ & \\
\hline
\end{tabular}

* Take the amount of $2 \mathrm{~L}$ as an example. The ingredients in A were added to $1.9 \mathrm{~L}$ distilled water, boiled, packed and then sterilized. The ingredients in B were directly added to $100 \mathrm{~mL}$ of sterilized water and shaken. 


\subsection{Soil Physical and Chemical Properties}

Potassium concentration was detected by a model AP 1500 flame photometer (Shanghai Instruments Group Co., Ltd., Shanghai, China) [26]. Soil pH and oxidation-reduction potential were measured in a soil suspension (1:2.5 soil to $\mathrm{H}_{2} \mathrm{O}$ ratio) by a PB-10 Basic $\mathrm{pH}$ Meter (Shanghai Sartorius Trading Co. Ltd., China) and a DDS-307A Conductivity Meter (Shanghai Inesa Scientific Instrument Co., Ltd., China), respectively. The Futura ${ }^{\mathrm{TM}}$ Continuous Flow Analytical System (Alliance Instruments, France) was used to quantify the ammonium nitrogen $\left(\mathrm{NH}^{4}{ }_{+}-\mathrm{N}\right)$, the nitrate-nitrogen $\left(\mathrm{NO}^{3} \_\mathrm{N}\right)$ and available phosphorus using the method described by Shitan Bao [27]. The organic matter content was determined using the dichromate digestion method [26].

\subsection{Strawberry Growth, Mortality and Yield}

Strawberry growth index was evaluated in both trial sites. Lack of funding resulted in the strawberry yield being monitored in Trial I only. After 120 days of strawberry transplant, 40 strawberry plants were randomly selected from each plot to measure stem thickness and plant height using the Vernier calipers and rulers. Two rows of strawberries were randomly selected from each plot to collect the yield data during the harvesting season (February 2018) in Trial I, and the yield of each row was recorded with each harvest. In May 2018, the mortality caused by strawberry blight was determined from two randomly selected rows from each plot.

The Chinese Traditional Spring Festival was in February in 2018. During this period, the selling price of strawberries is at its highest point. Therefore, in the experiment, we determined the highest average price of "Red Face" at this time (USD $4.4 \mathrm{~kg}^{-1}$ ), based in 2018 Beijing Xinfadi agricultural product market price forecast (http://www.xinfadi.com.cn), to calculate the grower's income.

\subsection{DNA Extraction and HTS Analysis}

DNA was extracted and purified from samples of $0.25 \mathrm{~g}$ of soils using the MoBio PowerSoil ${ }^{\circledR}$ DNA Isolation Kit (MoBio Technologies Inc., USA) following the manufacturer's instructions. After extraction, the quality of the DNA was evaluated by electrophoresis on a $0.5 \%(\mathrm{w} / \mathrm{v})$ agarose gel. The concentration of the DNA samples was measured by a NanoDrop ${ }^{\mathrm{TM}} 1000$ spectrophotometer (Thermo Fisher Scientific Inc., USA).

The V3-V4 region (general primer 338 F-806R) [28] and internal transcribed spacer (ITS) region (ITS 1 F-ITS2R) [29] were selected as the targets of the bacterial and fungal genes regions, respectively. Two universal primer pairs, namely $338 \mathrm{~F}$ (5'-ACTCCTACGGGAGGCAGCAG-3') 806R (5'-GGACTACHVGGGTWTCTAAT-3) and ITS1F (5'- CTTGGTCAT TTAGGAAGTAA-3)-ITS2R (5'-GCTGCGTTCTTCATCATGAGAC-3') were used to amplify the bacteria V3-V4 (350 nt) region and the fungal internal transcriptional spacer (ITS) (500 nt) hypervariable region, respectively. The illumina adapters 5'-AATGATACGGCGACCACCGAGATCTACAC-3' and 5'-CAAGCAGAAGACGGCATACGAGATGCCGCATTCGAT-3' were used. The polymerase chain reaction (PCR) amplifications were performed, recovered and quantified for each sample in accordance with the procedure described in a previous study [2]. The average length of the paired-end sequencing of bacteria and fungi PCR products was $417 \mathrm{bp}$ and $245 \mathrm{bp}$, respectively. The sequencing was performed using the Illumina Miseq system of Majorbio Bio-Pharm Technology Co., Ltd. (Shanghai, China). The sequencing procedure has been described in a previous study [2].

Majorbio Bio-Pharm Technology Co., Ltd. (Shanghai, China) analyzed the abundance and community structure of bacteria and fungi in the soil on the basis of the standard protocols described in the purified amplicons method with the Illumina MiSeq platform [30]. The Quantitative Insights Into Microbial Ecology (QIIME I 1.9.1) open-source bioinformatics pipeline was used for the post-sequencing analysis [31]. First, the sequences obtained were clustered into operational taxonomic units (OTUs) based on a 97\% similarity threshold with the UPARSE Pipeline v 7.0. The effective sequence depth was normalized to compare all samples at the same sequencing depth. On the basis of the cluster analysis, 
the alpha diversity indices (e.g., Chao and Shannon) were calculated and further compared by one-way ANOVA test $(p \leq 0.05)$ with the SPSS statistical software. Significant differences among means were evaluated using Tukey's HSD test at $p=0.05$. The taxonomy of each OTU's representative sequence was analyzed using the RDP Classifier (http://rdp.cme.msu.edu/). The OTUs' representative sequences were compared to the 16S rRNA database on the bacteria Silva (Release128 http://www.arb-silva.de) and to the fungi ITS database on the Unite (Release $7.0 \mathrm{http}: / /$ unite.ut.ee/index.php). The Bray-Curtis method was used to generate the Principal Coordinates Analysis (PCoA). The differences between groups of microbial diversity were tested by the Adonis method, and the number of replacements was set to 999. The statistical analysis was performed using the one-way ANOVA test ( $p \leq 0.05)$, and Falsely Discovery Rate (FDR) correction was used for the multiple correction test.

\subsection{Data Analysis}

The strawberry mortality rate $(\mathrm{X}, \%)$ was calculated using the Equation (1):

$$
\mathrm{X}=\frac{\mathrm{N} 1}{\mathrm{~N} 1+\mathrm{N} 2} \times 100
$$

where $\mathrm{X}$ is the strawberry mortality (\%), $\mathrm{N} 1$ is the number of dead strawberry plants in the two selected rows of each plot, and N2 is the number of live strawberry plants in the two selected rows of each plot.

The inhibition of soil-borne fungi pathogens by counting CFU (Equation (2)) was used to determine the control efficacy of ASD in relation to Fusarium spp. and Phytophthora spp. (based on CFU counting):

$$
\mathrm{Y}=\frac{\mathrm{Au}-\mathrm{At}}{\mathrm{Au}} \times 100
$$

where $\mathrm{Y}$ is the inhibition rate of fungi growth based on the counting CFU (\%), Au is the number of fungal colonies in the untreated control, and At is the number of fungal colonies in the treatment.

Field trial data (including strawberry plant height, stem thickness, mortality, yield and output value) and the soil's physical and chemical properties were analyzed using a one-way analysis of variance (ANOVA) by the SPSS of Windows v. 22.0 statistical software. The variance was analyzed after the strawberry plant growth and mortality data in percentages had been normalized through arcsine conversion. The yield and the data on the soil's physical and chemical properties were analyzed directly without any normalization. Significant differences among means were evaluated using Tukey's $H S D$ test at $p=0.05$ [32]. The figures were drawn with the OriginPro ${ }^{\circledR} 9.0$ (OriginLab Corp., USA) and Adobe Illustrator ${ }^{\circledR}$ CS6 (Adobe Systems Inc., USA) mapping software.

\section{Results}

\subsection{Fungi Soil-Borne Pathogens}

The results showed that the CCM 6 and the CCM 12 treatments significantly reduced the colonies of Fusarium spp. and Phytophthora spp. at the 0-20 cm depth of the soil, compared to the CK after 30 days of soil disinfestation (Figure 1). The ASD treatment reduced Fusarium spp. and Phytophthora spp. by $91 \%$ and $94 \%$, respectively, in the two trials. Nevertheless, the colonies of Fusarium spp and Phytophthora spp were recovered after 120 days, despite ASD treatment. ASD significantly increased the CFU of Fusarium spp. compared to CK in the two trials after 120 days. However, in the CCM 12 treatment, Fusarium spp. grew back to the same levels as in CK in Trial II. The quantity of Phytophthora spp. colonies recovered to the same level as they were at with CK in the two trials, except with the CCM 12 treatment, which maintained suppression in Trial I. 

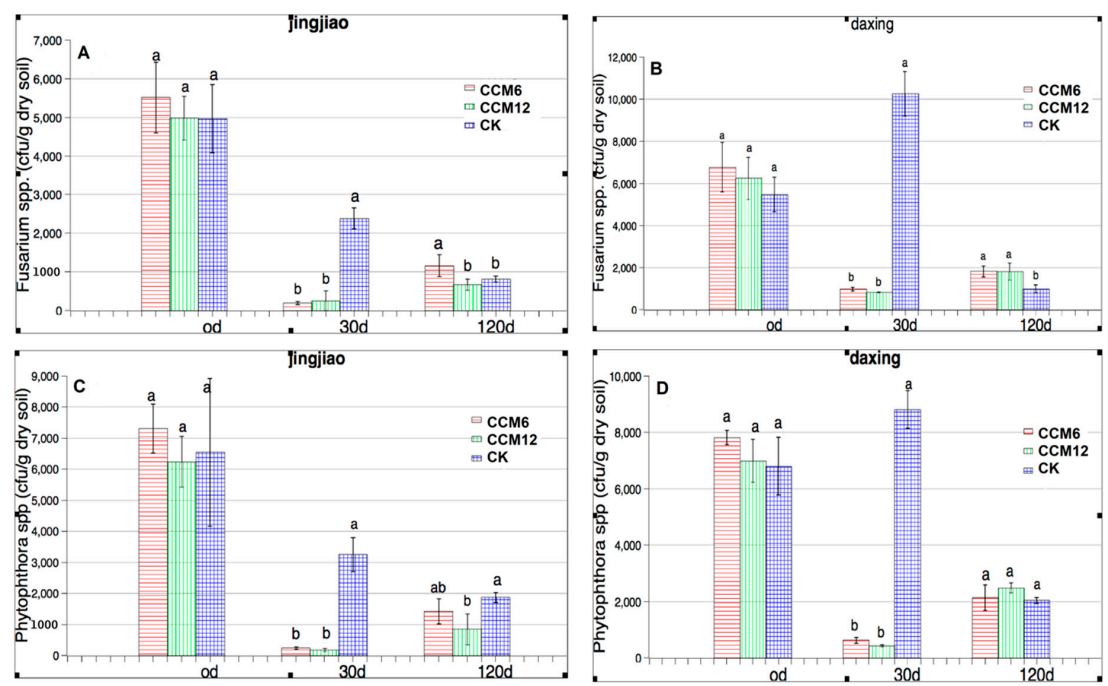

Figure 1. Colony-forming units per gram $\left(\mathrm{cfu} \mathrm{g}^{-1}\right)$ of selected species in $1 \mathrm{~g}$ of dry soil from the different treatment CFUs of Fusarium spp. in the Trial I (Jingjiao) (A) and Trial II (Daxing) (B) locations. CFUs of Phytophtora spp. at the Trial I (Jingjiao) (C) and the Trial II (Daxing) (D) locations. CCM $6=6$ tons/ha composted chicken manure, CCM $12=12$ tons/ha composted chicken manure, $\mathrm{CK}=$ untreated control. $0 \mathrm{~d}$ means the quantity of fungi in the soil on the first day. No organic matter or TIF were added on the first day of the experiment; $30 \mathrm{~d}$ means the quantity of fungi in the soil on the 30th day from the first day of the experiment; $120 \mathrm{~d}$ means the quantity of fungi in the soil on the 120th day from the first day of the experiment. Error bars represent the standard errors of means $(n=4)$. Data were analyzed for ANOVA. Duncan's new multiple range test was used to determine statistical differences $(p \leq 0.05)$.

\subsection{Soil Physicochemical Properties}

The soil ammonium nitrogen, soil nitrate-nitrogen and OM increased significantly after 30 days of ASD treatments, compared to the CK, and there was no difference between the CCM 6 and the CCM 12 (Table 3). The oxidation-reduction potential of the ASD treatments was significantly less (182 and $171 \mathrm{mv})$ than with CK $(213 \mathrm{mv})$. In addition, the available potassium of the CCM 12 treatment was significantly higher $\left(882 \mathrm{mg} \mathrm{kg}^{-1}\right)$ than that of CK $\left(750 \mathrm{mg} \mathrm{kg}^{-1}\right)$. However, CCM $6\left(773 \mathrm{mg} \mathrm{kg}^{-1}\right)$ did not show a significant difference from CK.

Table 3. Physicochemical property results of the soil after 30 days of ASD treatment.

\begin{tabular}{|c|c|c|c|c|c|c|c|}
\hline Treatment & $\begin{array}{l}\mathrm{NH}_{4}{ }^{+}-\mathrm{N} \\
(\mathrm{mg} / \mathrm{kg})\end{array}$ & $\begin{array}{l}\mathrm{NO}_{3}{ }^{-}-\mathrm{N} \\
(\mathrm{mg} / \mathrm{kg})\end{array}$ & $\begin{array}{c}\text { Available } \\
\text { Phosphorus } \\
\text { (mg/kg) }\end{array}$ & $\begin{array}{l}\text { Available } \\
\text { Potassium } \\
\text { (mg/kg) }\end{array}$ & $\begin{array}{c}\text { Organic } \\
\text { Matter } \\
(\mathrm{mg} / \mathrm{kg})\end{array}$ & $\begin{array}{l}\text { Oxidation-Reduction } \\
\text { Potential (mV) }\end{array}$ & $\mathrm{pH}$ \\
\hline CCM 6 & $16.1 \pm 1.17 \mathrm{a}$ & $92 \pm 1 \mathrm{a}$ & $942 \pm 134 \mathrm{a}$ & $773 \pm 86 b$ & $17.0 \pm 0.45 \mathrm{a}$ & $182 \pm 18 b$ & $7.59 \pm 0.88 a$ \\
\hline CCM 12 & $19.6 \pm 1.52 \mathrm{a}$ & $100 \pm 21 \mathrm{a}$ & $977 \pm 82 \mathrm{a}$ & $882 \pm 69 a$ & $17.1 \pm 2.9 \mathrm{a}$ & $171 \pm 22 b$ & $7.32 \pm 0.56 a$ \\
\hline CK & $13.8 \pm 3.60 \mathrm{~b}$ & $55 \pm 33 \mathrm{~b}$ & $906 \pm 73 a$ & $750 \pm 93 b$ & $13.9 \pm 1.9 \mathrm{~b}$ & $213 \pm 16 a$ & $7.76 \pm 0.53 \mathrm{a}$ \\
\hline
\end{tabular}

Means $(n=4)$. Data were analyzed using ANOVA. Means within the same column for soil physical and chemical properties followed by the same letter were not significantly different by the Duncan's new multiple range test at $p \leq 0.05$.

\subsection{Strawberry Growth, Mortality Rate and Yield}

In the present study, the strawberry plant height and stem thickness were significantly greater with soil fumigation than they were in CK in the two trials, except CCM 6 did not show a significant difference from the control in Trial I (Figure 2A-D). At the end of the experiment, CCM $6(3.2 \%, 4.1 \%)$ and CCM $12(2.5 \%, 2.9 \%)$ treatments significantly reduced strawberry mortality in the two trials, compared to CK $(12.4 \%, 15.8 \%)$ (Figure 2E,F). Strawberry yields were 5.0 and 5.3 tons ha ${ }^{-1}$ with CCM 6 and CCM 12 disinfestation, respectively, doubling the yield obtained with CK $\left(2.5\right.$ ton $\left.\mathrm{kg}^{-1}\right)$ in Trial I (Figure $\left.2 \mathrm{G}\right)$. The strawberry yield with the CCM 12 treatment was significantly higher than the CCM 6 in Trial I. 
Trial I
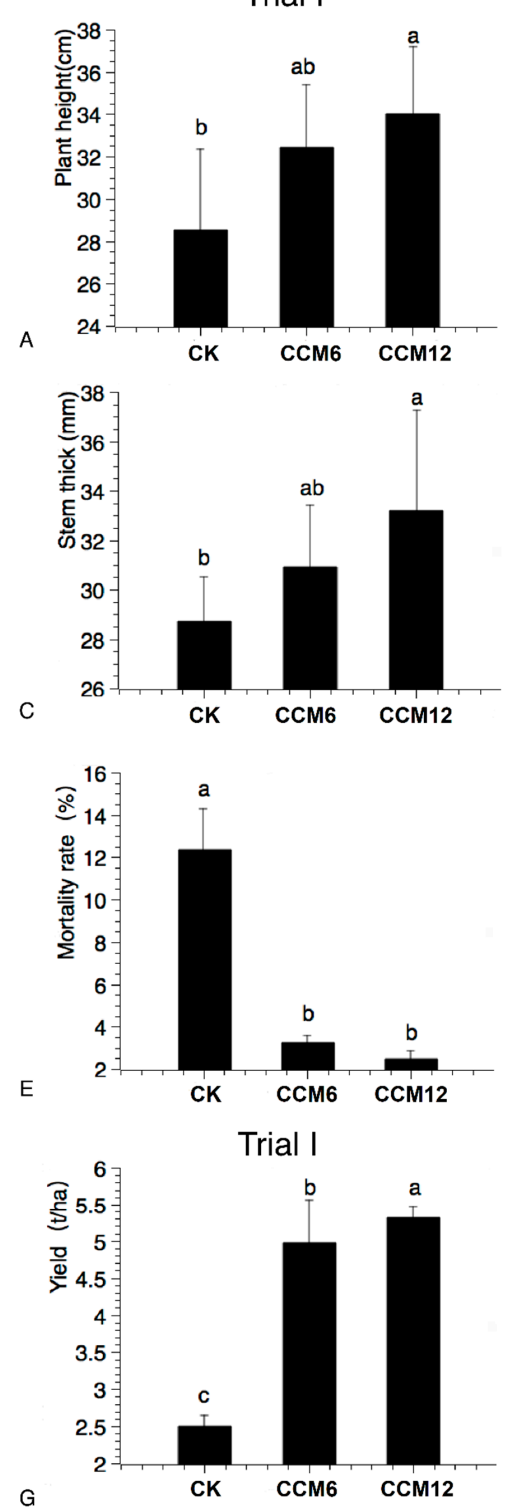

Trial II
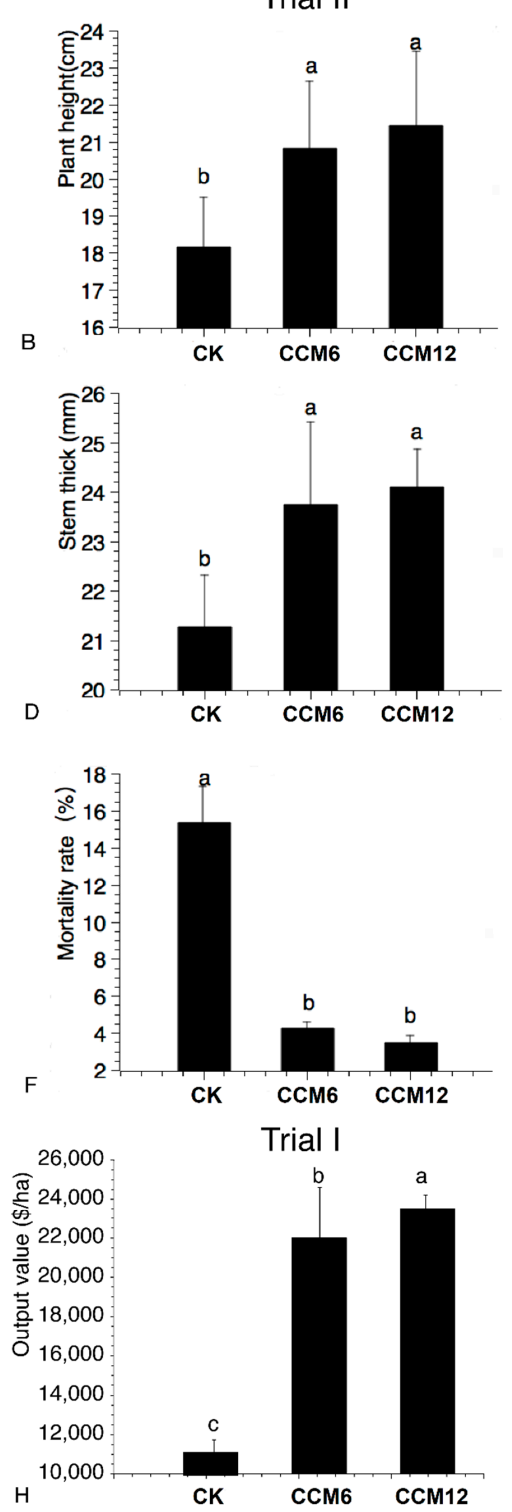

Figure 2. Effect of the composted chicken manure amendments for ASD on strawberry growth (A-D), mortality $(\mathbf{E}, \mathbf{F})$, yield and income $(\mathbf{G}, \mathbf{H})$ during the assay. Comparison between ASD and untreated control (CK) treatment in the two greenhouse trials. CCM $6=6$ tons/ha composted chicken manure, $\mathrm{CCM} 12=12$ tons/ha composted chicken manure, $\mathrm{CK}=$ untreated control. The strawberry output value was for one month (February 2018). We use the highest average price of the "Hongyan" strawberry (USD $4.43 \mathrm{~kg}^{-1}$ ), based on the Beijing Xinfadi agricultural product market price forecast for February 2018 (http://www.xinfadi.com.cn) to calculate the strawberry output value. Error bars represent the standard errors of means $(n=4)$. Different letters mean significant differences between treatments. Data were analyzed for ANOVA. Duncan's new multiple range test was used to determine statistical differences $(p \leq 0.05)$.

The increased cost of ASD is negligible compared to the benefits of increased strawberry production. CCM 6 and CCM 12 could significantly increase strawberry-based economic income by USD 10,937-12,449 $\mathrm{ha}^{-1}$ in February for growers (Figure 2H). The costs of CCM 6 and CCM 12 were USD 4969 and $5669 \mathrm{ha}^{-1}$, respectively (the cost of TIF is USD $4285 \mathrm{ha}^{-1}$, and the cost of CCM is USD $114 \mathrm{ha}^{-1}$ ). The net increases in income from strawberry production were USD 5968 and $6780 \mathrm{ha}^{-1}$ after ASD fumigation in February, for CCM 6 and CCM 12, respectively. 


\subsection{Soil Microbial Diversity Analysis}

The HTS for bacteria yielded 590,359 raw sequences clustered in 7742 OTUs (Figure 3a). For fungi, 1299 OTUs were clustered from 781,886 raw sequences, all generated from all soil samples after ASD fumigation (Figure $3 b$ ).
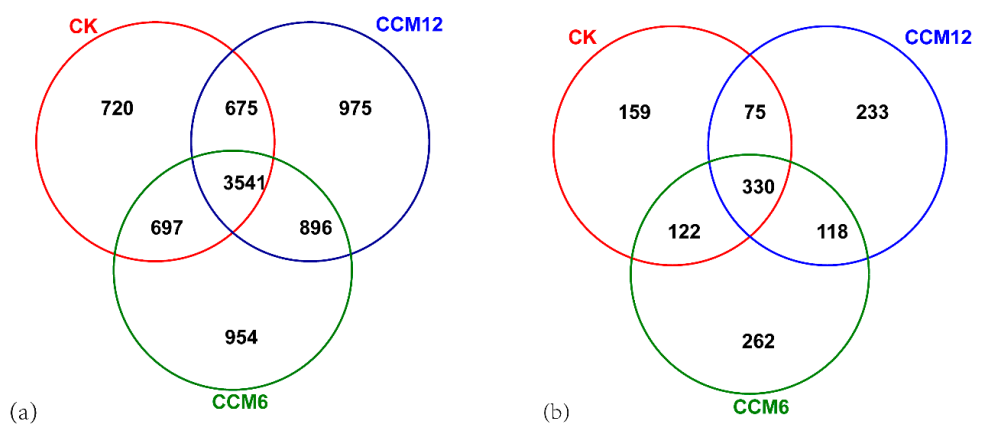

Figure 3. Soil bacteria (a) and fungi (b) Venn diagrams showing the shared and the unique OTUs as a result of the different treatments. CCM $6=6$ tons/ha composted chicken manure, CCM $12=12$ tons/ha composted chicken manure, $\mathrm{CK}=$ untreated control. Soil samples were collected from each plot on 26 July 2017 in Trial I, and 10 August 2017 in Trial II.

In the study, CCM 6 (Chao index, $p=0.016$; Shannon index, $p=0.023$ ) increased the bacterial richness and diversity compared to $\mathrm{CK}$. At a higher $\mathrm{OM}$ level, the increase was significantly less (Figure 4A,C). The fungal diversity showed no difference between all treatments (Figure 4B). However, CCM 6 (Chao index, $p=0.023$ ) led to a higher fungal richness than the other treatments (Figure 4D).
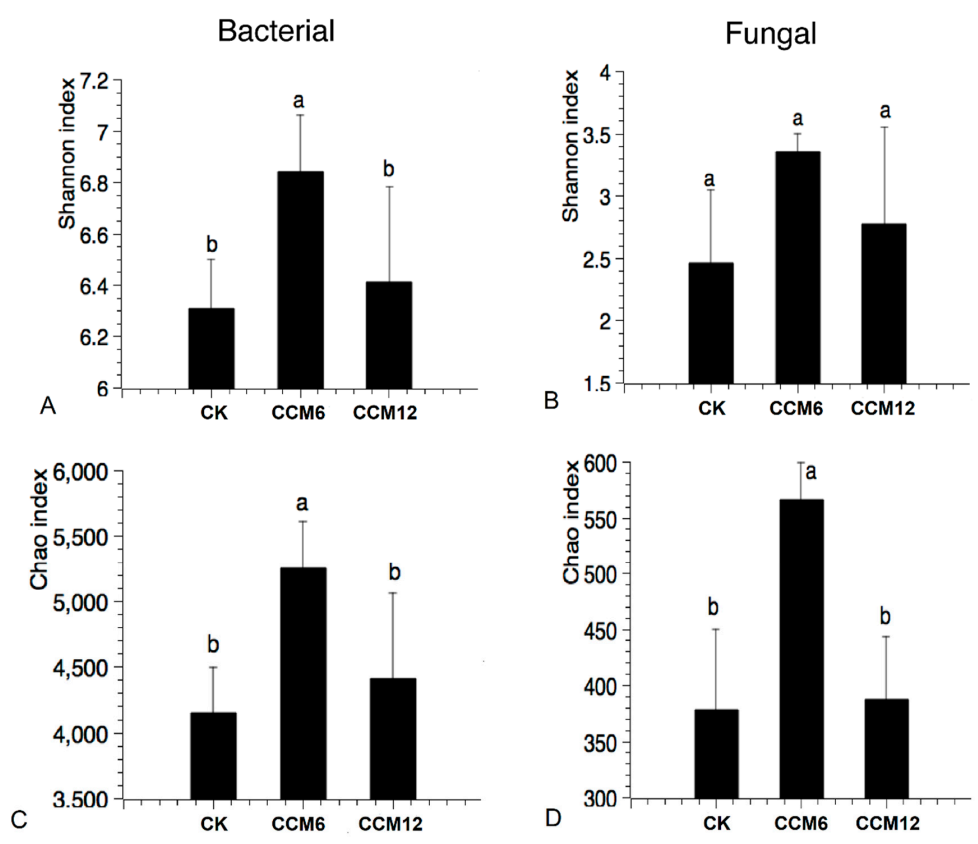

Figure 4. Analysis of the Alpha diversity index among different treatments at the operational taxonomic unit (OTU) level. The bacterial (A) and fungal (B) Shannon index were chosen for the community's diversity and the bacterial (C) and fungal (D) Chao index was choose for communities richness in the soil samples. CCM $6=6$ tons/ha composted chicken manure, CCM $12=12$ tons/ha composted chicken manure, $\mathrm{CK}=$ untreated control. Error bars represent the standard errors of means $(n=3)$. Different letters mean significant differences between treatments. Data were analyzed for Student's t-test. Significant differences among means were evaluated using the Tukey's HSD test at $p=0.05$. 
Based on the PCoA analysis, the results suggest that ASD treatments changed the soil bacterial and fungal microbial communities' compositions compared to CK (Figure 5). At the soil bacterial phyla level (Figure 6a), ASD fumigation significantly increased the relative abundance of OTUs, classified into Chloroflexi $(p=0.02274)$ and Bacteroidetes $(p=03414)$, compared to CK. Thirty-one soil bacterial genera showed significant differences between treated and untreated samples (Figure 6b). The relative abundance of bacteria genera from the families of Anaerolineaceae, Rhodothermaceae and Caldilineaceae, and the genera Chryseolinea and Anaeromyxobacter, significantly increased with soil fumigation. ASD fumigation greatly reduced the relative abundance of Bacillus, Streptomyces, Defluviicoccus and Enhygromyxa.
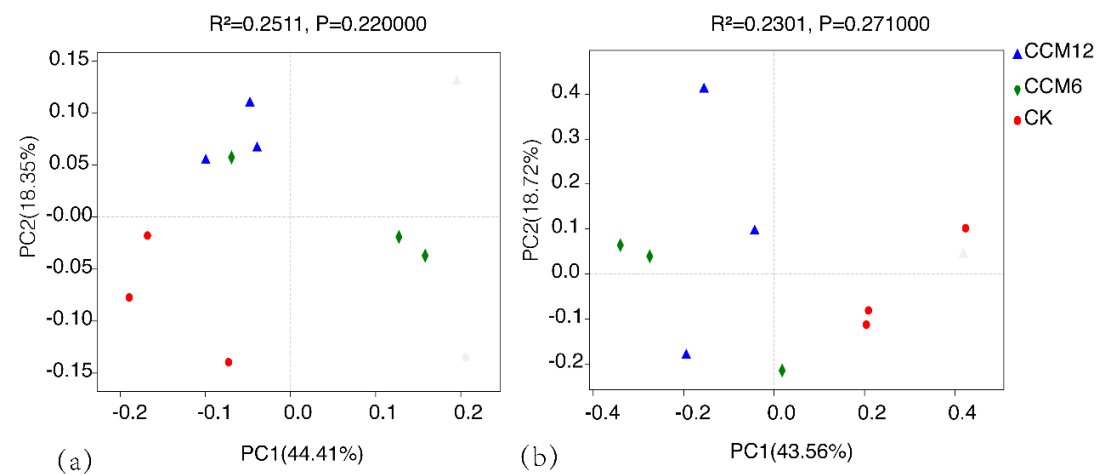

Figure 5. Principal coordinate analysis diagram of bacteria (a) and fungi (b) after treatments at the OTU level (based on the Bray-Curtis method). CCM $6=6$ tons/ha composted chicken manure, CCM $12=12$ tons/ha composted chicken manure, $\mathrm{CK}=$ untreated control.

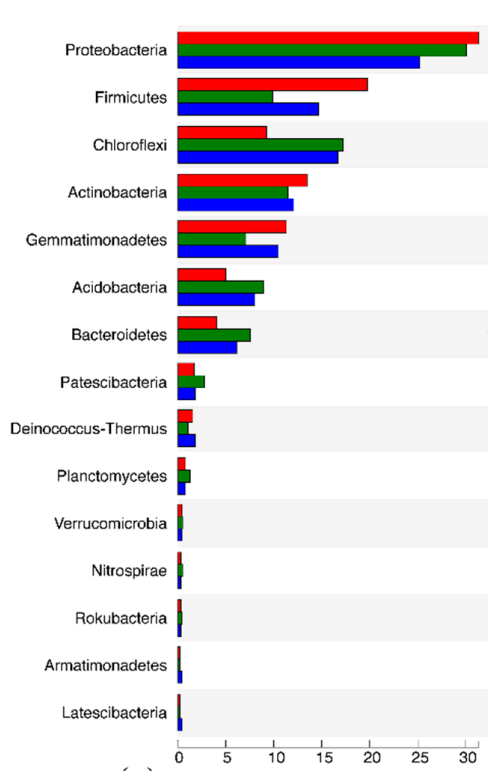

(a)

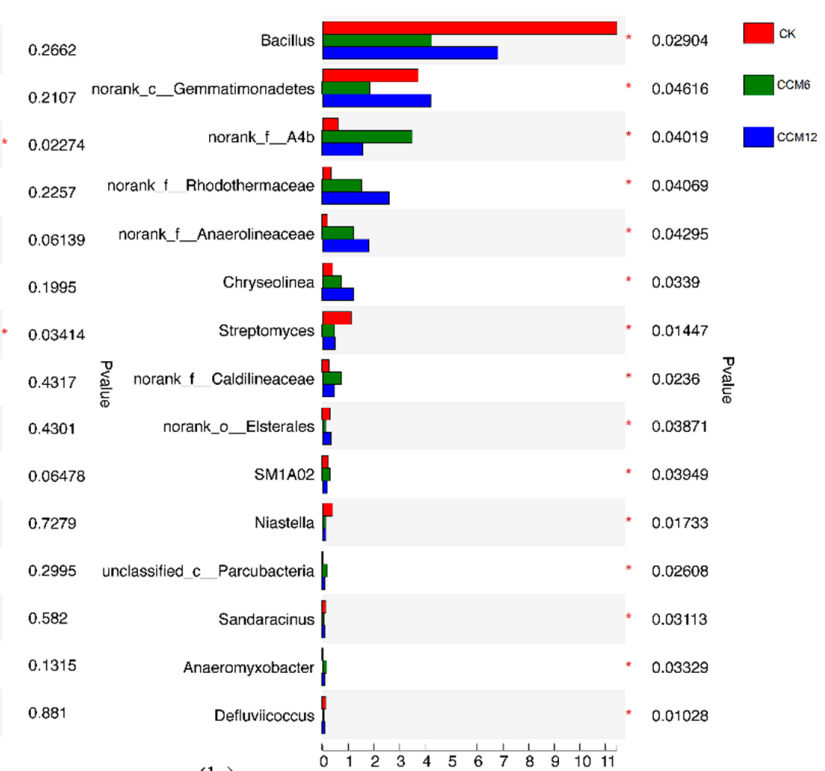

(b)

Figure 6. Comparison of relative abundances of the soil bacteria phyla (a) and genera (b) detected in histograms of the various soil microbial compositions exposed among different treatment groups. CCM $6=6$ tons/ha composted chicken manure, CCM $12=12$ tons/ha composted chicken manure, $\mathrm{CK}=$ untreated control. The number of asterisks indicates a significant difference between treatments in accordance with the one-way ANOVA test $(p \leq 0.05)$. Falsely Discovery Rate (FDR) correction was used for the multiple correction test, and Scheffe was used for post-hoc tests.

At the fungal phyla level (Figure 7a), compared with CK, the CCM 12 treatment significantly reduced the relative abundance of the genus Fusarium spp. $(p=0.0220)$ by $54 \%$ (Figure $7 \mathrm{~b}$ ). However, 
the ASD fumigation methods significantly increased the beneficial fungi Trichoderma spp. $(p=0.0366)$ by $3055 \%$ and $1600 \%$, respectively $(p<0.05)$.

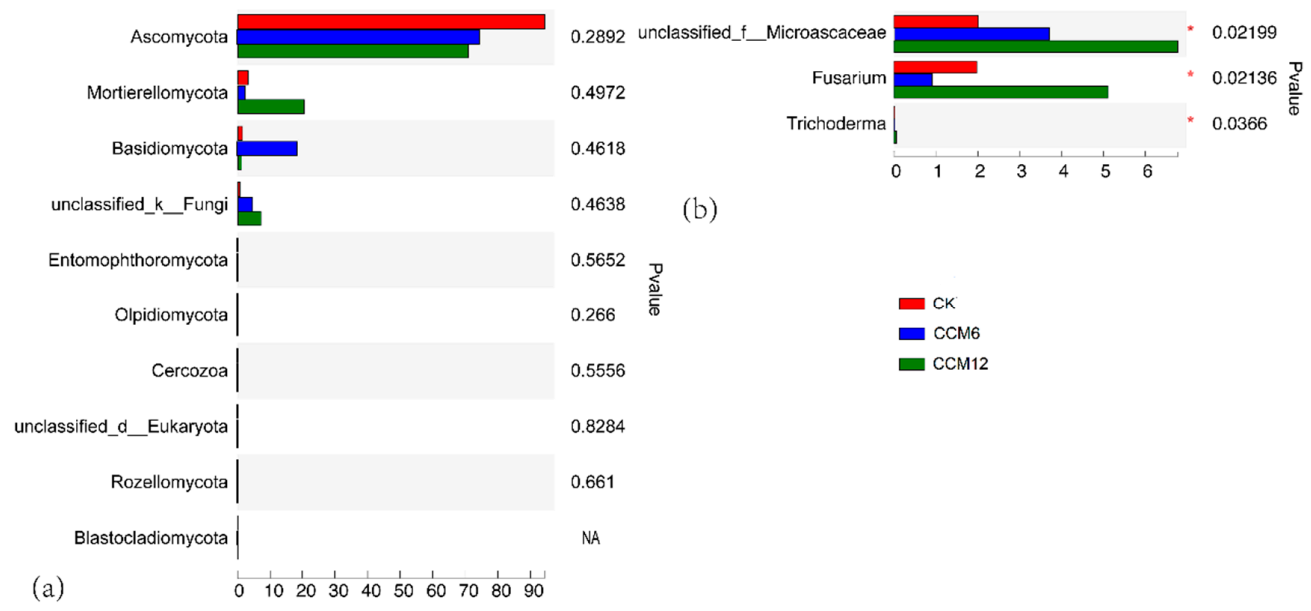

Figure 7. Comparison of relative abundances of the soil fungal phyla (a) and genera (b) detected in histograms of the various soil microbial compositions exposed among the different treatment groups. CCM $6=6$ tons/ha composted chicken manure, CCM $12=12$ tons/ha composted chicken manure, $\mathrm{CK}=$ untreated control. The number of asterisks indicates a significant difference between treatments in accordance with the one-way ANOVA test $(p \leq 0.05)$. Falsely Discovery Rate (FDR) correction was used for the multiple correction test, and Scheffe was used for post-hoc tests.

\section{Discussion}

\subsection{Effect of ASD on Fungal Pathogens}

ASD's efficacy against soil pathogens can be variable, and depends on the target pathogens in the soil and the used carbon source [17]. In our field trials, the results showed that ASD had a highly suppressive effect on Fusarium spp. and Phytophthora spp. (Figure 1). The test results from the two experimental trials remained consistent (Figure 1a-d). In another case study, Termorshuizen reported that the compost suppressive activity in the pathosystems Fusarium oxysporum on flax and Phytophthora nicotianae on tomato was otherwise conducive in the Verticillium dahlia-eggplant combination [33]. Ammonia and nitrous acid production has been identified as a mechanism for pathogen and root-knot nematode control, with the use of high-nitrogen inputs alone (including composted or un-composted animal manure) [34] or in combination with solarization effects [35]. In general, mixed compost has a better disease suppression effect on pathogenic bacteria than pure compost [36]. In our experiments, however, the pathogens recovered their original levels 120 days after treatment. Liu et al. showed that F. oxysporum, in watermelon cultivation, regenerated 90 days after ASD disinfestation, and this conclusion is consistent with our results [37].

\subsection{Effect of ASD on the Soil Physicochemical Properties}

Various organic amendments can help improve soil quality [38,39]. ASD using CCM can significantly increase the content of ammonium nitrogen and $\mathrm{OM}$ in the soil, and significantly reduce the content of nitrate-nitrogen, which indicates that the ASD process will affect the mineralization of soil nitrogen. In most studies $(73 \%, n=426)$, OM addition is either effective in, or detrimental to, the inhibition of specific pathogens in the soil. The decomposition of OM is the key process affecting inhibition in the short-term (days or weeks) or the long-term (months or years [17,40]). Butler et al. (2014) reported that ASD-treated soils are reductive, with lower oxidation-reduction potential than the control [17]. 


\subsection{Effect of ASD on Strawberry Growth and Yield}

The results showed that strawberry plants grown from compost-fertilized plots exhibited generally higher and thicker stems, and better fruit weights. Animal manure and compost are organic sources of nutrients, and have been widely demonstrated to increase the soil OM, improve soil quality and increase crop yield [13]. Research has shown that the leaf areas, the number of flowers, the branch weight and the total strawberry yield could be increased significantly in a plot treated with compost, compared to in plots that receive only inorganic fertilizers [41].

These results suggest that the strawberry yield could improve when the dose of CCM increases. For effective disease suppression, relatively high rates of amendment incorporation are reported as necessary by Mowlick [13,42]. The research has shown that, with the increase in the amount of chicken manure in the field, the growth parameters of several vegetables and corn plants increased significantly [43]. The yield of the strawberry fruit from plants grown in CCM 12-treated soil was significantly $(7 \%)$ higher than that grown in CCM 6-treated soil. The CCM 12 costs USD $695 \mathrm{ha}^{-1}$ more than CCM 6, which is calculated from composting chicken manure costing USD $114 \mathrm{ha}^{-1}$. However, strawberry farmers can increase profits by up to USD $1512 \mathrm{ha}^{-1}$ just based on the strawberry harvest in February.

\subsection{Effect of ASD on Soil Microbial Diversity and Community}

CCM 6 had a significant impact on the bacterial and fungal diversity and richness after ASD fumigation. ASD effectivity is influenced by the production of volatile organic compounds and organic acids, lethal anaerobic conditions, and changes in soil microbial communities [14]. The ASD treatments tend to increase the Chao and Shannon indices of bacterial and fungal communities in the soil. In the literature, the Shannon-Wiener index for soil without fumigation was significantly lower than that of the ASD-treated and flooded soil, incorporated with $1.6 \%(\mathrm{w} / \mathrm{w})$ pig manure [44]. Butler used a partially composted poultry litter amendment for ASD, which could potentially improve the soil microbial diversity of low organic soils [11].

ASD fumigation affected the fungal and bacterial community taxonomy, leading to the abundance of functional microbial communities such as anaerobic and organic matter decomposition. In the current study, ASD fumigation increased the relative abundance of bacteria $g$ _norank $f$ _Anaerolineaceae, norank $f$ __Rhodothermaceae and Anaerolinea (Figure 6a and Figure S1). Anaerolineaceae spp. play a key role in the initial activation of long-chain n-alkane biodegradation [45]. Anaerolinea spp. are a strictly anaerobic Gram-negative bacteria that can ferment sugar to produce acetic acid and hydrogen, and can utilize lactate, acetate and ethanol [46]. The growth of aerobic microorganisms consumes the remaining soil oxygen, and gives rise to anaerobic soil conditions [37,47-49]. The anaerobic bacteria that were grown in the biological disinfestation-treated soil play an important role in significantly degrading the Fusarium pathogen [50]. ASD fumigation reduced the relative abundance of Bacillus and Streptomyces in the soil (Figure 6b). An antagonistic strain of Bacillus subtilis Y-IVI was reported to control the Fusarium wilt caused by Fusarium oxysporum f. sp. Melonis [51]. According to the literature, plant-pathogenic Streptomyces species can cause parasitic plant diseases in the underground structures of diverse plant species. For example, Streptomyces scabiei infects the underground tubers of potatoes, causing common scab disease [52].

The CCM 12 treatment significantly reduced the abundance of the fungi Fusarium (Figure 7b). Ueki et al. showed that two anaerobic, isolates identified as Clostridium beijerinckii, had severely degraded the mycelial cells of the Fusarium pathogen of spinach wilt disease during anaerobic co-incubation [50]. Furthermore, the CCM 6 and the CCM 12 treatments increased the beneficial fungi Trichoderma (Figure 7b). Since the 1920s, Trichoderma has been known for its biocontrol of plant pathogens [53]. A meta-analysis showed that ASD promotes the population of the Trichoderma [13]. 


\section{Conclusions}

The results of this study show that the CCM and TIF can play an important role in ASD's suppressive effect on soil-borne diseases. The fumigation efficacy with ASD increased, and the responses in strawberry yield, soil nutrition and soil microbial communities were modified, compared to the control. The colonies of Fusarium spp. and Phytophthora spp., which are recognized to cause strawberry soil-borne diseases, decreased significantly after ASD. The marketable income from strawberries was greater after ASD disinfestation, and this economic benefit could be due to the suppression of soil-borne diseases and the improvement of soil nutrition.

The research monitored the changes of the bacterial and fungal communities' relative compositions after ASD fumigation. In brief, our research observed that ASD significantly increased the richness of the soil bacterial and fungal community, and significantly increased the proportions of the Anaerolineaceae family, and more specifically the Anaerolinea genus, which could be vital under the lethal anaerobic condition. The proportion of the beneficial fungi Trichoderma spp. increased significantly with soil treatment, and this could lead to a pest and disease incidence reduction during the production of strawberries. The improved efficacy of ASD may result from the TIF, which created a significantly anaerobic soil condition. In their study, the authors of [54] showed that TIF not only reduces emissions, but also improves efficacy, with better fumigant-retention under the film.

Future research is needed in order to continue addressing the challenges of soil-borne disease-control in different types of soil, and cover type for ASD technology for crops. In addition, the type of compost and application amount both need to be evaluated separately in order to expand the application, and beneficial microbial agents can be added to enhance the effects of ASD.

Supplementary Materials: The following are available online at http://www.mdpi.com/2071-1050/12/16/6313/s1.

Author Contributions: Conceptualization, Z.S. and A.C.; Investigation, D.Y.; Methodology, H.C.; Project administration, Y.L.; Resources, C.O.; Software, M.E. and C.B.; Supervision, A.C.; Validation, Q.W.; Writing-original draft, Z.S.; Writing—review and editing, Z.S., S.M. and A.C. All authors have read and agreed to the published version of the manuscript.

Funding: This research was funded by the National Key Research and Development Program of China, grant number 2017YFD0201600, and National Natural Science Foundation Project of China, grant number 31972313. The APC was funded by National Key Research and Development Program of China.

Acknowledgments: We thank Meixia Guo, Xiaoqin Wo, Qianrui Wang, Changpeng Luo, Chubo Deng and Beijing Jiexi Agricultural Technology Co., Ltd. for their help in the field trials.

Conflicts of Interest: The authors declare no conflict of interest.

\section{References}

1. Han, D.; Yan, D.; Cao, A.; Fang, W.; Wang, X.; Song, Z.; Li, Y.; Ouyang, C.; Guo, M.; Wang, Q. Study on the Hydrolysis Kinetics of Dimethyl Disulfide. Water Air Soil Pollut. 2017, 228. [CrossRef]

2. Zhang, D.; Yan, D.; Fang, W.; Huang, B.; Wang, X.; Wang, X.; Zhu, J.; Liu, J.; Ouyang, C.; Li, Y.; et al. Chloropicrin Alternated with Biofumigation Increases Crop Yield and Modifies Soil Bacterial and Fungal Communities in Strawberry Production. Sci. Total Environ. 2019, 675, 615-622. [CrossRef] [PubMed]

3. Mao, L.; Jiang, H.; Zhang, L.; Zhang, Y.; Sial, M.U.; Yu, H.; Cao, A. Combined Effect of a Reduced Dose of 1,3-Dichloropropene and Dimethyl Disulfide on Soilborne Pests and Tomato Growth. Crop Prot. 2019, 121, 1-6. [CrossRef]

4. Ajwa, H.A.; Klose, S.; Nelson, S.D.; Minuto, A.; Gullino, M.L.; Lamberti, F.; Lopez-Aranda, J.M. Alternatives to Methyl Bromide in Strawberry Production in the United States of America and the Mediterranean Region. Phytopathol. Mediterr. 2003, 42, 220-244.

5. López-Aranda, J.M.; Gómez, F.; Puga, M.; Zamora, R.; Daugovish, O.; Cotero, M.A. Chemical Soil Fumigation for Raspberry Nursery in Jalisco (Mexico). J. Berry Res. 2016, 6, 37-46. [CrossRef]

6. Donley, N. The USA Lags behind Other Agricultural Nations in Banning Harmful Pesticides. Environ. Health 2019, 18, 1-12. [CrossRef] 
7. Fennimore, S.A.; Serohijos, R.; Samtani, J.B.; Ajwa, H.A.; Subbarao, K.V.; Martin, F.N.; Daugovish, O.; Legard, D.; Browne, G.T.; Muramoto, J.; et al. Tif Film, Substrates and Nonfumigant Soil Disinfestation Maintain Fruit Yields. Calif. Agric. 2013, 67, 139-146. [CrossRef]

8. Food and Agriculture Organization (FAO). Food and Agriculture Organization of the United Nations: FAOSTAT Database Collections. 2017. Available online: http://faostat.fao.org/ (accessed on 29 July 2020).

9. Bi, Y.M.; Tian, G.L.; Wang, C.; Zhang, Y.; Wang, D.N.; Zhang, F.F.; Zhang, L.S.; Sun, Z.J. Differential Effects of Two Earthworm Species on Fusarium wilt of Strawberry. Appl. Soil Ecol. 2018, 126, 174-181. [CrossRef]

10. Holmes, G.J.; Mansouripour, S.M.; Hewavitharana, S.S. Strawberries at the Crossroads: Management of Soilborne Diseases in California Without Methyl Bromide. Phytopathology 2020, 110, 956-968. [CrossRef]

11. Butler, D.M.; Kokalis-Burelle, N.; Albano, J.P.; McCollum, T.G.; Muramoto, J.; Shennan, C.; Rosskopf, E.N. Anaerobic Soil Disinfestation (ASD) Combined with Soil Solarization as a Methyl Bromide Alternative: Vegetable Crop Performance and Soil Nutrient Dynamics. Plant Soil 2014, 378, 365-381. [CrossRef]

12. Hewavitharana, S.S.; Mazzola, M. Carbon Source-Dependent Effects of Anaerobic Soil Disinfestation on Soil Microbiome and Suppression of Rhizoctonia Solani AG-5 and Pratylenchus Penetrans. Phytopathology 2016, 106, 1015-1028. [CrossRef] [PubMed]

13. Shrestha, U.; Augé, R.M.; Butler, D.M. A Meta-Analysis of the Impact of Anaerobic Soil Disinfestation on Pest Suppression and Yield of Horticultural Crops. Front. Plant Sci. 2016, 7, 1-20. [CrossRef] [PubMed]

14. Strauss, S.L.; Kluepfel, D.A. Anaerobic Soil Disinfestation: A Chemical-Independent Approach to Pre-Plant Control of Plant Pathogens. J. Integr. Agric. 2015, 14, 2309-2318. [CrossRef]

15. Browne, G.T.; Ott, N.; Poret-Peterson, A.; Gouran, H.; Lampinen, B. Efficacy of Anaerobic Soil Disinfestation for Control of Prunus Replant Disease. Plant Dis. 2018, 102, 209-219. [CrossRef]

16. Muramoto, J.; Shennan, C.; Zavatta, M.; Baird, G.; Toyama, L.; Mazzola, M. Effect of Anaerobic Soil Disinfestation and Mustard Seed Meal for Control of Charcoal Rot in California Strawberries. Int. J. Fruit Sci. 2016, 16, 59-70. [CrossRef]

17. Shennana, C.; Muramoto, J.; Mazzola, M.; Momma, N.; Kobara, Y.; Lamers, J.; Rosskopf, E.N.; Kokalis-Burelle, N.; Butler, D.M. Anaerobic Soil Disinfestation for Soil Borne Disease Control in Strawberry and Vegetable Systems: Current Knowledge and Future Directions. Acta Hortic. 2014, 1044, 165-175. [CrossRef]

18. Han, S.H.; An, J.Y.; Hwang, J.; Kim, S.B.; Park, B.B. The Effects of Organic Manure and Chemical Fertilizer on the Growth and Nutrient Concentrations of Yellow Poplar (Liriodendron tulipifera Lin.) in a Nursery System. For. Sci. Technol. 2016, 12, 137-143. [CrossRef]

19. Tilston, E.L.; Pitt, D.; Groenhof, A.C. Composted Recycled Organic Matter Suppresses Soil-Borne Diseases of Field Crops. New Phytol. 2002, 731-740. [CrossRef]

20. Jiang, T.; Schuchardt, F.; Li, G.; Guo, R.; Zhao, Y. Effect of C/N Ratio, Aeration Rate and Moisture Content on Ammonia and Greenhouse Gas Emission during the Composting. J. Environ. Sci. 2011, 23, 1754-1760. [CrossRef]

21. Larney, F.J.; Hao, X. A Review of Composting as a Management Alternative for Beef Cattle Feedlot Manure in Southern Alberta, Canada. Bioresour. Technol. 2007, 98, 3221-3227. [CrossRef]

22. Koike, S.T.; Gordon, T.R. Management of Fusarium wilt of Strawberry. Crop Prot. 2015, 73, 67-72. [CrossRef]

23. Zhang, Y. Identification and Characterization of a Bacillus subtilis strain TS06 as Bio-Control Agent of Strawberry Replant Disease (Fusarium and Verticilium Wilts). Afr. J. Biotechnol. 2012, 11, 570-580. [CrossRef]

24. Komada, H. Development of a Selective Medium for Quantitative Isolation of Fusarium Oxysporum from Natural Soil. Rev. Plant Prot. Res. 1975, 8, 114-124.

25. Masago, H.; Yoshikawa, M.; Fukada, M.; Nakanishi, N. Selective Inhibition of Pythium Spp. on a Medium for Direct Isolation of Phytophthora Spp. from Soils and Plants. Phytopathology 1977, 77, 425-428. [CrossRef]

26. Schinner, F.; Öhlinger, R.; Kandeler, D.E.; Margesin, R. Methods in Soil Biology. In Methods in Soil Biology; Springer: Berlin, Germany, 1995; pp. 386-389.

27. Shidan, B. (Ed.) Soil Agrochemical Analysis, 3rd ed.; China Agriculture Press: Beijing, China, 2005.

28. Xu, N.; Tan, G.; Wang, H.; Gai, X. Effect of Biochar Additions to Soil on Nitrogen Leaching, Microbial Biomass and Bacterial Community Structure. Eur. J. Soil Biol. 2016, 74, 1-8. [CrossRef]

29. Massart, S.; Olmos, A.; Jijakli, H.; Candresse, T. Current Impact and Future Directions of High Throughput Sequencing in Plant Virus Diagnostics. Virus Res. 2014, 188, 90-96. [CrossRef] 
30. Bokulich, N.A.; Subramanian, S.; Faith, J.J.; Gevers, D.; Gordon, J.I.; Knight, R.; Mills, D.A.; Caporaso, J.G. Quality-Filtering Vastly Improves Diversity Estimates from Illumina Amplicon Sequencing. Nat. Methods 2013, 10, 57-59. [CrossRef]

31. Massart, S.; Martinez-Medina, M.; Jijakli, M.H. Biological Control in the Microbiome Era: Challenges and Opportunities. Biol. Control 2015, 98-108. [CrossRef]

32. Mao, L.; Wang, Q.; Yan, D.; Ma, T.; Liu, P.; Shen, J.; Li, Y.; Ouyang, C.; Guo, M.; Cao, A. Evaluation of Chloropicrin as a Soil Fumigant against Ralstonia Solanacarum in Ginger (Zingiber Officinale Rosc.) Production in China. PLoS ONE 2014, 9. [CrossRef]

33. Messiha, N.A.S.; Van Diepeningen, A.D.; Wenneker, M.; Van Beuningen, A.R.; Janse, J.D.; Coenen, T.G.C.; Termorshuizen, A.J.; Van Bruggen, A.H.C.; Blok, W.J. Biological Soil Disinfestation (BSD), a New Control Method for Potato Brown Rot, Caused by Ralstonia Solanacearum Race 3 Biovar 2. Eur. J. Plant Pathol. 2007, 117, 403-415. [CrossRef]

34. Scheuerell, S.J.; Sullivan, D.M.; Mahaffee, W.F. Suppression of Seedling Damping-off Caused by Pythium Ultimum, P. Irregulare, and Rhizoctonia Solani in Container Media Amended with a Diverse Range of Pacific Northwest Compost Sources. Phytopathology 2005, 95, 306-315. [CrossRef] [PubMed]

35. Oka, Y.; Shapira, N.; Fine, P. Control of Root-Knot Nematodes in Organic Farming Systems by Organic Amendments and Soil Solarization. Crop Prot. 2007, 26, 1556-1565. [CrossRef]

36. Termorshuizen, A.J.; van Rijn, E.; van der Gaag, D.J.; Alabouvette, C.; Chen, Y.; Lagerlöf, J.; Malandrakis, A.A.; Paplomatas, E.J.; Rämert, B.; Ryckeboer, J.; et al. Suppressiveness of 18 Composts against 7 Pathosystems: Variability in Pathogen Response. Soil Biol. Biochem. 2006, 38, 2461-2477. [CrossRef]

37. Liu, L.; Chen, S.; Zhao, J.; Zhou, X.; Wang, B.; Li, Y.; Zheng, G.; Zhang, J.; Cai, Z.; Huang, X. Watermelon Planting Is Capable to Restructure the Soil Microbiome That Regulated by Reductive Soil Disinfestation. Appl. Soil Ecol. 2018, 129, 52-60. [CrossRef]

38. Gamliel, A.; van Bruggen, A.H.C. Maintaining Soil Health for Crop Production in Organic Greenhouses. Sci. Hortic. 2016, 208, 120-130. [CrossRef]

39. Van Bruggen, A.H.C.; Gamliel, A.; Finckh, M.R. Plant Disease Management in Organic Farming Systems. Pest Manag. Sci. 2016, 72, 30-44. [CrossRef] [PubMed]

40. Sollins, P.; Homann, P.; Caldwell, B.A. Stabilization and Destabilization of Soil Organic Matter: Mechanisms and Controls. Geoderma 1996, 74, 65-105. [CrossRef]

41. Arancon, N.Q.; Edwards, C.A.; Bierman, P.; Welch, C.; Metzger, J.D. Influences of Vermicomposts on Field Strawberries: 1. Effects on Growth and Yields. Bioresour. Technol. 2004, 93, 145-153. [CrossRef]

42. Mowlick, S.; Takehara, T.; Kaku, N.; Ueki, K.; Ueki, A. Proliferation of Diversified Clostridial Species during Biological Soil Disinfestation Incorporated with Plant Biomass under Various Conditions. Appl. Microbiol. Biotechnol. 2013, 97, 8365-8379. [CrossRef]

43. Amos, H.; Obi, C.I.; Audu, I. Effect of Chicken Manure on the Performance of Vegetable Maize (Zea Mays Saccharata) Varieties under Irrigation. Discourse J. Agric. Food Sci. 2013, 1, 190-195.

44. Huang, X.Q.; Wen, T.; Zhang, J.B.; Meng, L.; Zhu, T.B.; Liu, L.L. Control of Soil-Borne Pathogen Fusarium Oxysporum by Biological Soil Disinfestation with Incorporation of Various Organic Matters. Eur. J. Plant Pathol. 2015, 143, 223-235. [CrossRef]

45. Liang, B.; Wang, L.Y.; Zhou, Z.; Mbadinga, S.M.; Zhou, L.; Liu, J.F.; Yang, S.Z.; Gu, J.D.; Mu, B.Z. High Frequency of Thermodesulfovibrio Spp. and Anaerolineaceae in Association with Methanoculleus Spp. in a Long-Term Incubation of n-Alkanes-Degrading Methanogenic Enrichment Culture. Front. Microbiol. 2016, 7, 1-13. [CrossRef] [PubMed]

46. Sekiguchi, Y.; Yamada, T.; Hanada, S.; Ohashi, A.; Harada, H.; Kamagata, Y. Anaerolinea Thermophila Gen. Nov., Sp. Nov. and Caldilinea Aerophila Gen. Nov., sp. Nov., Novel Filamentous Thermophiles That Represent a Previously Uncultured Lineage of the Domain Bacteria at the Subphylum Level. Int. J. Syst. Evol. Microbiol. 2003, 53, 1843-1851. [CrossRef]

47. Fan, X.Y.; Gao, J.F.; Pan, K.L.; Li, D.C.; Zhang, L.F.; Wang, S.J. Shifts in Bacterial Community Composition and Abundance of Nitrifiers during Aerobic Granulation in Two Nitrifying Sequencing Batch Reactors. Bioresour. Technol. 2018, 251, 99-107. [CrossRef]

48. Guo, H.; Di Gioia, F.; Zhao, X.; Ozores-Hampton, M.; Swisher, M.E.; Hong, J.; Kokalis-Burelle, N.; DeLong, A.N.; Rosskopf, E.N. Optimizing Anaerobic Soil Disinfestation for Fresh Market Tomato Production: Nematode and Weed Control, Yield, and Fruit Quality. Sci. Hortic. 2017, 218, 105-116. [CrossRef] 
49. Poret-Peterson, A.T.; Albu, S.; McClean, A.E.; Kluepfel, D.A. Shifts in Soil Bacterial Communities as a Function of Carbon Source Used during Anaerobic Soil Disinfestation. Front. Environ. Sci. 2019, 6, 1-15. [CrossRef]

50. Ueki, A.; Kaku, N.; Ueki, K. Role of Anaerobic Bacteria in Biological Soil Disinfestation for Elimination of Soil-Borne Plant Pathogens in Agriculture. Appl. Microbiol. Biotechnol. 2018, 102, 6309-6318. [CrossRef]

51. Zhao, Q.; Ran, W.; Wang, H.; Li, X.; Shen, Q.; Shen, S.; Xu, Y. Biocontrol of Fusarium wilt Disease in Muskmelon with Bacillus Subtilis Y-IVI. BioControl 2013, 58, 283-292. [CrossRef]

52. Loria, R.; Bukhalid, R.A.; Fry, B.A.; King, R.R. Plant Pathogenicity in the Genus Streptomyces. Plant Dis. 1997, 81, 836-846. [CrossRef]

53. Harman, G.E. Overview of Mechanisms and Uses of Trichoderma spp. Phytopathology 2006, 96, 190-194. [CrossRef]

54. Gao, S.; Sosnoskie, L.M.; Cabrera, J.A.; Qin, R.; Hanson, B.D.; Gerik, J.S.; Wang, D.; Browne, G.T.; Thomas, J.E. Fumigation Efficacy and Emission Reduction Using Low-Permeability Film in Orchard Soil Fumigation. Pest Manag. Sci. 2016, 72, 306-314. [CrossRef] [PubMed]

C 2020 by the authors. Licensee MDPI, Basel, Switzerland. This article is an open access article distributed under the terms and conditions of the Creative Commons Attribution (CC BY) license (http://creativecommons.org/licenses/by/4.0/). 